\title{
Skin carriage of the Micrococcaceae
}

\author{
W. C. NOBLE \\ From the Department of Bacteriology, St John's Hospital for Diseases of the Skin, Lisle Street, \\ Leicester Square, London
}

SYNOPSIS The micrococcal flora of the skin of 382 children and 378 adults have been investigated using a scheme derived from the work of Baird-Parker (1963). The predominant groups are Staphylococcus type 2 and Micrococcus type 2. Some differences in the carriage at different sites have been found: in general the nose, axillae, groin, and toe webs have a similar flora but this differs a little from other, glabrous skin sites.

Bacteria of the family Micrococcaceae, ie, Grampositive, catalase-positive cocci are very common on human skin.

Until recently, however, there was no really satisfactory way of dividing the family into smaller groups. One member of the group Staphylococcus aureus, defined by its ability to coagulate human and other plasmas, has received a great deal of attention, for it has an undoubted ability to cause disease in man and animals. The remaining members of the group are often lumped into the 'scrap heap' genus Micrococcus and the term Sarcina reserved for the aerobic, yellow-pigmented, packet-forming members.

Baird-Parker $(1963,1965)$ devised a scheme based on the series of simple tests which enabled a total of 15 subgroups to be recognized amongst the Micrococcaceae. The two major genera are Staphylococcus, whose members are able to grow and produce acid from glucose under anaerobic conditions, and Micrococcus whose members have not this ability.

The scheme devised by Baird-Parker enabled Micrococcaceae of the skin to be classified. This paper reports the results of an investigation on the skins of persons outside the hospital environment.

\section{MATERIALS}

The scheme of classification is shown in the figure. Anaerobic utilization of glucose was measured in $4 \times$ $\frac{1}{2}$ in. tubes using the medium described by BairdParker (1963). Aerobic sugar fermentation was studied in peptone water medium with Andrade's indicator; acetoin production (Voges-Proskauer reaction) was measured in the medium described by Baird-Parker (1963) using Barritt's modification. Only strong reactions were read as positive and this may have led to difficulties in interpretation which are discussed later. Phosphatase production was studied on phenol-phthalein-phosphate Received for publication 27 August 1968. agar (Barber and Kuper, 1951). In contrast to BairdParker's method, all cultures were incubated at $37^{\circ} \mathrm{C}$ : acetoin medium for seven days, and all other tests for three days only.

In an attempt to collect Micrococcaceae from populations uninfluenced by exposure to the hospital environment, school children aged 11 to 18 , training college students, and RAF personnel were examined. No difference was discernible between, for example, respondents from different colleges, and, since in some places the response equalled $100 \%$ of available individuals, it was not thought that the process of calling for 'volunteers' has significantly biased the results.

\section{METHODS}

Samples were taken from all individuals, using cottontipped swabs moistened in nutrient broth, from the nose, mouth, chest, periumbilicus, groin, thigh, shin, scapula, lumbar back, forearm, and fourth toe web of one foot. Adults were also swabbed in the axilla and on the forehead and cheek. Swabs were inoculated onto blood agar (half plate per swab) and incubated aerobically for 24 hours at $37^{\circ} \mathrm{C}$ and for two days at bench temperature $\left(20^{\circ}\right.$ to $\left.25^{\circ}\right)$. Representatives of all colonies which in any way resembled the Micrococcaceae were subcultured onto nutrient agar, with the exception of unequivocal Staphylococcus aureus and Sarcina colonies. (In this paper the term 'Sarcina' has been retained for the aerobic, yellowpigmented, tetrad-forming organisms.) Morphology was checked by Gram stain or by nigrosin-negative staining and the cultures were inoculated into peptone water before sugar fermentation tests. The catalase test was carried out on the nutrient agar cultures. Finally the cultures were coded according to the scheme shown in the Figure.

\section{RESULTS}

In the adult population representatives of the Micrococcaceae were recovered from $91 \%$ of nasal swabs, 


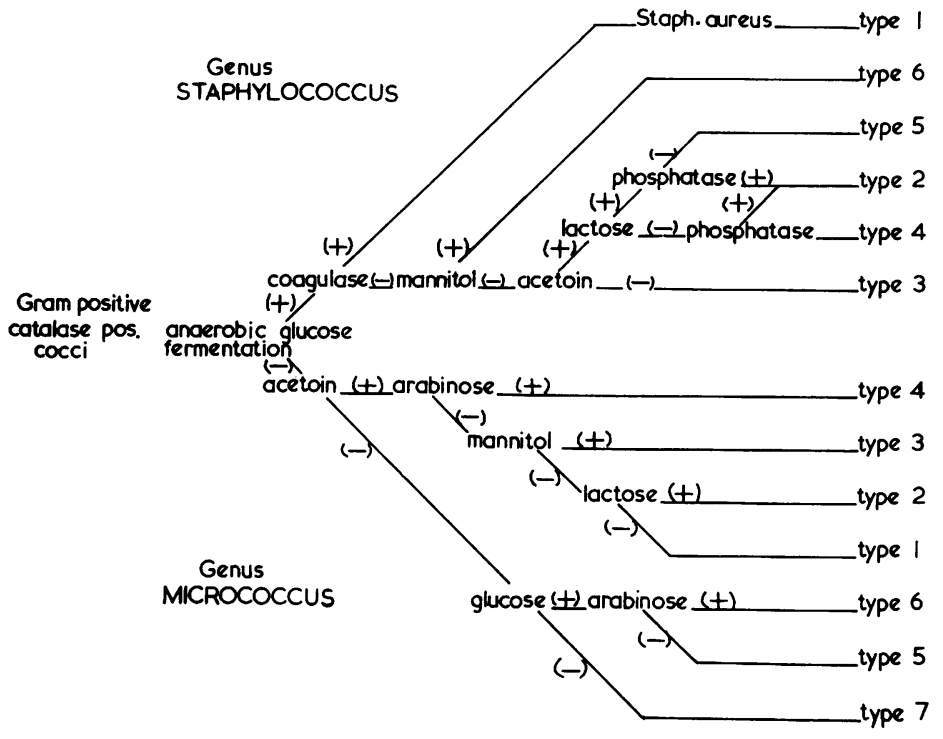

FIG. 1 Taxonomic scheme derived from the work of Baird-Parker.

$13 \%$ of mouth swabs, $96 \%$ of chest, $94 \%$ of periumbilicus, $99 \%$ of groin, $93 \%$ of thigh, $96 \%$ of shin, $95 \%$ of shoulder, $94 \%$ of back, $91 \%$ of forearm, $100 \%$ of toe webs, $92 \%$ of axilla, and $99 \%$ each of forehead and cheek swabs. The results from children were very similar. The basic distributions are shown in Tables I and II. It can be seen that the major groups of Micrococcaceae on the skin are Staphylococcus type 2/3, Micrococcus type $2 / 5$, and Sarcina. Very small numbers of representatives of other Baird-Parker groups were also isolated but are not included in these Tables. In both the children and adults the Staphylococcus type 2/3 was isolated more frequently from the nose, groin, toe webs, and face than from other sites; this was in general also a feature of the carriage of Staphylococcus aureus.
There was a marked sex difference in the carriage of Staphylococcus aureus (Table III) amongst the child-o ren, but not amongst the adults. It was more difficult to get 'deep' groin swabs in the adult population and ${ }^{\circ}$ this may account for less marked differences between $\overline{\bar{z}}$ male and female adults.

It was not possible in this series to attempt to differentiate between 'resident' and 'transient' carriage of the Micrococcaceae except for Staphylococcus aureus. In Table IV the total carriage of Staph. aureus has been divided on a quantitative 3 basis, the recovery of more than six colonies of Staphylococcus on the agar plate being regarded as evidence of resident carriage (Noble, 1966). It can be seen that the sites which have the highest carrier rates also carried the greatest number of organisms.

TABLE I

PERCENTAGE CARRIAGE OF MICROCOCCACEAE AT SPECIFIED SITES IN 382 SCHOOL CHILDREN AGED 11 TO 18 YeARS

\begin{tabular}{|c|c|c|c|c|c|c|c|c|}
\hline \multirow[b]{2}{*}{ Site } & \multicolumn{8}{|c|}{ Percentage Carriage of } \\
\hline & $S 1$ & $S 2 / 3$ & $S 6$ & $M I$ & $M 2 / 5$ & M 3 & $M 7$ & Sarcina \\
\hline Nose & 49 & 36 & 8 & 1 & 21 & 1 & 1 & 8 \\
\hline Mouth & 2 & 2 & 1 & 1 & 5 & 1 & 1 & 1 \\
\hline Chest & 3 & 22 & 4 & 4 & 30 & 7 & 3 & 38 \\
\hline Periumbilicus & 3 & 15 & 3 & 4 & 30 & 4 & 2 & 42 \\
\hline Groin & 6 & 35 & 5 & 5 & 44 & 3 & 2 & 31 \\
\hline Thigh & 2 & 18 & 3 & 4 & 37 & 8 & 3 & 40 \\
\hline Scapula & $\overline{2}$ & 14 & 3 & 1 & 30 & 5 & 2 & 50 \\
\hline Lumbar back & 3 & 15 & 4 & 3 & 35 & 6 & 3 & 50 \\
\hline Forearm & 3 & 13 & 4 & 3 & 28 & 4 & 1 & 37 \\
\hline Toe webs & 5 & 29 & 4 & 4 & 67 & 7 & 3 & 23 \\
\hline
\end{tabular}
Percentage Carriage of 
TABLE II

PERCENTAGE CARRIAGE OF MICROCOCCACEAE AT SPECIFIED SITES IN 378 ADULTS AGED 19 to 62 YeARS

Percentage Carriage of

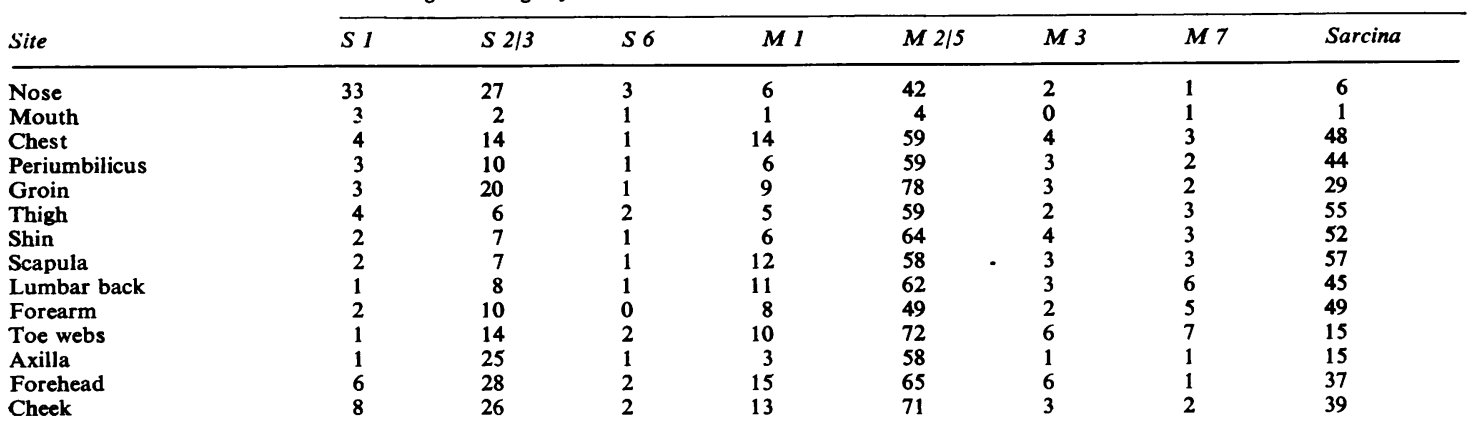

TABLE III

CARRIAGE OF Staphylococcus aureus

\begin{tabular}{|c|c|c|c|c|}
\hline \multirow[b]{3}{*}{ Site } & \multicolumn{4}{|c|}{ Percentage Carriage } \\
\hline & \multicolumn{2}{|l|}{ Children } & \multicolumn{2}{|l|}{ Adults } \\
\hline & 195 Males & 187 Females & 116 Males & 262 Females \\
\hline $\begin{array}{l}\text { Nose } \\
\text { Mouth } \\
\text { Chest } \\
\text { Periumbilicus } \\
\text { Groin } \\
\text { Thigh } \\
\text { Shin } \\
\text { Shoulder } \\
\text { Lumbar back } \\
\text { Forearm } \\
\text { Toe webs } \\
\text { Axilla } \\
\text { Forehead } \\
\text { Cheek }\end{array}$ & $\begin{array}{l}61 \\
1 \cdot 5 \\
4 \cdot 5 \\
4 \\
9 \\
3 \cdot 5 \\
3 \cdot 5 \\
2 \cdot 5 \\
4 \cdot 5 \\
3 \cdot 5 \\
8 \cdot 5 \\
\text { ND } \\
\text { ND } \\
\text { ND }\end{array}$ & $\begin{array}{l}38 \\
3 \\
1 \cdot 5 \\
2 \\
2 \\
1 \\
1 \cdot 5 \\
1 \cdot 5 \\
1 \cdot 5 \\
1 \cdot 5 \\
0 \cdot 5 \\
\text { ND } \\
\text { ND } \\
\text { ND }\end{array}$ & $\begin{array}{l}34 \\
1 \\
2 \\
1 \\
3 \cdot 5 \\
3 \cdot 5 \\
1 \\
2 \\
0 \\
2 \cdot 5 \\
1 \\
1 \cdot 5 \\
3 \\
3\end{array}$ & $\begin{array}{l}33 \\
3 \\
4 \\
4 \\
3 \cdot 5 \\
4 \\
3 \\
2 \cdot 5 \\
2 \\
2 \cdot 5 \\
2 \\
2 \\
6 \\
\end{array}$ \\
\hline
\end{tabular}

${ }^{1} \mathrm{ND}=$ Not done

TABLE IV

PERCENTAGE OF SITES WITH RESIDENT AND TRANSIENT CARRIAGE OF Staphylococcus aureus

\begin{tabular}{|c|c|c|c|c|}
\hline \multirow[b]{2}{*}{ Site } & \multicolumn{2}{|l|}{ Children (382) } & \multicolumn{2}{|l|}{ Adults (378) } \\
\hline & $\begin{array}{l}\text { Resident } \\
(>6 \text { colonies })\end{array}$ & $\begin{array}{l}\text { Transient } \\
(<6 \text { colonies })\end{array}$ & $\begin{array}{l}\text { Resident } \\
(>6 \text { colonies })\end{array}$ & $\begin{array}{l}\text { Transient } \\
\text { ( }<6 \text { colonies })\end{array}$ \\
\hline Nose & $45 \cdot 5$ & 3 & $32 \cdot 5$ & $1 \cdot 5$ \\
\hline Mouth & 1 & $1 \cdot 5$ & 1 & 1.5 \\
\hline Chest & 0.5 & 3 & 0.5 & 3 \\
\hline Periumbilicus & 1 & $2 \cdot 5$ & 0.5 & 3 \\
\hline Groin & $3 \cdot 5$ & 1 & $2 \cdot 5$ & 1 \\
\hline Thigh & $1 \cdot 5$ & $2 \cdot 5$ & 0.5 & 4 \\
\hline Shin & 0 & $2 \cdot 3$ & 0 & 2 \\
\hline Scapula & 0.5 & $1 \cdot 5$ & 0 & 2 \\
\hline Lumbar back & 0.5 & 3 & 0 & 1 \\
\hline Forearm & $0 \cdot 5$ & $2 \cdot 5$ & 0.5 & $1 \cdot 5$ \\
\hline Toe webs & $3 \cdot 5$ & 1 & $1 \cdot 5$ & 0 \\
\hline Axilla & ND $^{1}$ & ND & $1 \cdot 5$ & 0 \\
\hline Forehead & ND & ND & 1 & 4.5 \\
\hline Cheek & ND & ND & 3 & 4 \\
\hline
\end{tabular}

'ND $=$ Not done 
MULTIPle CARRIAGE OF MICROCOCCACEAE Since patients with diseases such as eczema have a higher carrier rate of Staphylococcus type 2 as well as Staphylococcus aureus than do persons with normal skin it was thought useful to see in this series whether 'resident' carriage of Staphylococcus aureus was associated in any way with carriage of the other Micrococcaceae. In order to obtain adequate numbers from a single site the analysis is confined here to nasal carriage. The results were divided according to the absence of Staphylococcus aureus or the presence of resident Staphylococcus aureus; swabs showing apparent transient carriage were omitted from the analysis. Of 446 swabs without Staphylococcus aureus, $28 \%$ yielded Staphylococcus type $2 / 3,43.5 \%$ Micrococcus type $2 / 5$, and $15.5 \%$ yielded diphtheroids only. For 297 swabs yielding resident Staphylococcus aureus the figures were $27.5 \%, 35.5 \%$, and $22 \%$ respectively. Thus there is a suggestion that conditions that favour the presence and presumably the growth of Staphylococcus aureus in the nose are slightly less favourable to the presence of Micrococcus type 2/5 but the difference is not statistically significant. Carriage of the Staphylococcus type $2 / 3$ in the nose did not appear to be related to carriage of Staph. aureus.

Of 1,451 samples from which two or more isolates were examined, 439 yielded more than one member of the Micrococcaceae other than Staph. aureus or Sarcina. The most common combinations were S 2 and $M 242 \%, M 1$ and $M 230 \%, M 2$ and $M 38 \%$, $\mathrm{M} 2$ and $\mathrm{M} 76 \%$, S 2 and M $14.5 \%$.

AXILLARY FLORA It was thought that an analysis of the flora of the axilla in relation to the use of axillary deodorants might yield some information on factors affecting the presence of various organisms, but no such effect could be demonstrated (Table V).

TABLE V

AXILLARY FLORA IN RELATION TO THE USE OF DEODORANTS

\begin{tabular}{|c|c|c|c|c|}
\hline \multirow{2}{*}{$\begin{array}{l}\text { Number } \\
\text { Sampled }\end{array}$} & \multicolumn{4}{|c|}{ Percentage with Dominant Flora } \\
\hline & $\begin{array}{l}\text { Staphylococcus } \\
\text { Type } 2\end{array}$ & $\begin{array}{l}\text { Micrococcus } \\
\text { Type } 2\end{array}$ & $\begin{array}{l}\text { Coliform Type } \\
\text { Organisms }\end{array}$ & 'Sterile' \\
\hline
\end{tabular}

Persons

using

176

Persons

not using

deodorants 31

29

31

55

No effect of the use of aluminium chlorhydrates as distinct from hexachloraphene deodorants could be shown.

\section{DISCUSSION}

In this series of investigations more members of the genus Micrococcus have been isolated from the skin음 surfaces than have been reported by other workers. There may be two major reasons for this apparent? dissimilarity. One is the difference in the populations? and sites chosen for sampling. Baird-Parker (1963음 and 1965) obtained his skin strains largely from the hands and axillae and from skin burns although he reported that many of the strains isolated from the air were micrococci, which may well have come fromhuman sources. The second major difference is in the $\cdot$ temperature at which the strains were incubated. An $\vec{\omega}$ initial trial with 20 strains failed to reveal anys difference between the two methods but when large? numbers of acetoin-negative Micrococcus strainsĩ were isolated from the skin a larger selection of $\omega$ isolates was tested at both temperatures. In a trial of 150 strains, seven gave different results at $30^{\circ} \mathrm{C}$ and $\overrightarrow{0}$ $37^{\circ} \mathrm{C}$ for the anaerobic glucose test $\left(30^{\circ} \mathrm{C}\right.$ six days'윽 incubation, $37^{\circ} \mathrm{C}$ three days' incubation). A retest of these strains in which duplicate tubes were used $>$ showed that tubes sealed with paraffin oil and incubated at $30^{\circ} \mathrm{C}$ for six days gave the same results $\vec{\omega}$ as with three days at $37^{\circ} \mathrm{C}$ for five of the seven strains. Two strains remained equivocal. Similar equivocal results have been reported by Schuhardt (1965).

This suggests that a small number of organisms may exist which are capable of utilizing very small quantities of oxygen. Cowan and Steel (1964) and $\frac{\circ}{D}$ Kocur and Mortensen (1967) showed that at $35^{\circ} \mathrm{\varrho}$ very different results for anaerobic glucose fermen- $\overline{\bar{O}}$ tation were obtained using Hugh and Leifson's medium compared with that of Baird-Parker and the standard medium proposed by the International Sub Committee on Taxonomy of Staphylococci and죠 Micrococci.

In the present series of experiments incubation at $37^{\circ} \mathrm{C}$ has clearly not produced a very high percentage $\stackrel{\varnothing}{\delta}$ of deviants from the results that one might have expected to obtain by rigidly following Baird-o Parker's technique.

In the same 150 strains aerobic glucose fermenta- $\frac{D}{2}$ tion correlated perfectly at both temperatures $\left(30^{\circ} \mathrm{C}\right.$, two weeks' incubation, $37^{\circ} \mathrm{C}$ three days' $\sigma$ incubation) but four strains showed a change from $\mathrm{N}$ weak to strong fermentation of lactose (in one strain $\mathrm{N}$ the $37^{\circ} \mathrm{C}$ culture was strong and the $30^{\circ} \mathrm{C}$ culture ${ }_{\sigma}^{\omega}$ weak). A further three strains showed weak to strong changes in mannitol (in one strain $37^{\circ} \mathrm{C}$ culture was strong). In no instance was a complete discrepancy found, ie, negative at one temperature, positive at the other.

For acetoin production, however, there were more $\stackrel{\overrightarrow{\mathbb{D}}}{\vec{D}}$ marked differences. If only the strong acetoin $\frac{\rho}{\mathbb{D}}$ reactions were read as positive, 28 strains gave 음 equivocal results at the two temperatures; in $15 \%$ of the strains the $37^{\circ} \mathrm{C}$ culture was regarded as 8 
positive and the other as negative. Retesting showed that these strains were relatively weak acetoin producers, and, since in the survey material weak reactions were regarded as negative the results are difficult to interpret. For this reason in the analysis the groups $\mathbf{S} 2$ and $S \mathbf{3}$ have been combined under the heading S $2 / 3$ and the groups $M 2$ and $M 5$ under the heading $M 2 / 5$.

The interest in the coagulase-negative, Grampositive, catalase-positive cocci lies in the possibility that some of them may be opportunist or feeble pathogens. Such organisms are not infrequently isolated from cases of subacute bacterial endocarditis, from patients undergoing heart surgery or insertion of a Spitz-Holter valve (eg Smith, Beals, Kingsbury, and Hasencleaver, 1958; Resnekov, 1959; Burns and Holtman, 1960; Callaghan, Cohen, and Stewart, 1961; Fischer and McArtor, 1967; Branson, 1968; Spink and Strong, 1968). There is evidence that the strains causing such sepsis are more often of the genus Staphylococcus (S $2-\mathrm{S} 5)$ than Micrococcus. In contrast the patients with coccal urinary tract infection often have organisms of the Baird-Parker type M 3 (Roberts, 1967; Mitchell, $1965,1968)$. As shown in this series, carriage of $M 3$ is not so frequent on the skin as of M 2 and this reinforces the suggestion that the M 3 strains have a special propensity to infect the urinary tract.

The results suggest that the type $M 1$ is more common on those areas of skin with a generally greasy surface (face, shoulders, back). The S 2 strains resemble Staph. aureus in their great propensity to colonize the nose, groin, axilla, and toes, and it is not therefore surprising that, like Staph. aureus, they are being implicated in disease processes.

The results obtained for Staphylococcus aureus in general resemble those of others. Polakoff, Richards, Parker, and Lidwell (1967) found no sex differences in perineal or axillary carriage of Staphylococcus aureus in swabs obtained from anaesthetized patients, although it has been shown that females disperse less Staph. aureus than males and this would seem likely to be related to skin carriage (eg Bethune, Blowers, Parker, and Pask, 1965; Emslie, 1966). In this series, in which the male and female schoolchildren were from exactly comparable environments, there were sex differences in carriage of Staph. aureus, but no such difference could be demonstrated amongst the adults.

I am indebted to Dr W. Cormack, MOH, London Borough of Harrow, and to Air Commodore Yerbury, DGMS, Royal Air Force, for help in obtaining access to the various populations and to all the staff and students at the schools and colleges and camps who took part in the survey. I wish to thank the many people involved in collecting and identifying the specimens.

\section{REFERENCES}

Baird-Parker, A. C. (1963). J. gen. Microbiol., 30, 409. (1965). Ibid., 38, 363 .

Barber, M., and Kuper, S. W. A. (1951). J. Path. Bact., 63, 65.

Bethune, D. W., Blowers, R., Parker, M., and Pask, E. A. (1965). Lancet, 1, 480.

Branson, D. (1968). Bact. Proc., p. 71.

Burns, J., and Holtman, D. F. (1960). Ann. N.Y. Acad. Sci., 88, 1115. Callaghan, R. P., Cohen, S. J., and Stewart, G. T. (1961). Brit. med. J., 1,860 .

Cowan, S. T., and Steel, K. J. (1964). J. Bact., 88, 804.

Emslie, J. A. N. (1966). Lancet, 1, 660.

Fischer, M. J., and McArtor, R. E. (1967). Ohio St. med. J., 63, 1325.

Kocur, M., and Mortensen, N. (1967). Acta path. microbiol. scand., $71,141$.

Mitchell, R. G. (1965). Brit. med. J., 1, 1127.

(1968). J. clin. Path., 21, 93.

Noble, W. C. (1966). Ibid., 19, 570.

Polakoff, S., Richards, I. D. G., Parker, M. T., and Lidwell, O. M. (1967). J. Hyg. (Lond.), 65, 559.

Resnekov, L. (1959). Lancet, 2, 597.

Roberts, A. P. (1967). J. clin. Path., 20, 631.

Schuhardt, V. T. (1965). Ann. N.Y. Acad. Sci., 128, 19.

Smith, I. M., Beals, P. D., Kingsbury, K. R., and Hasenclever, H. F. (1958). Arch. intern. Med., 102, 375.

Spink, M. S., and Strong, S. (1968). J. Path. Bact., 95, 295. 